\title{
Work Characteristics and Fathers' Vocabulary to Infants in African American Families
}

\author{
Nadya Pancsofara, Lynne Vernon-Feagans, Erika C. Odom, and The Family Life Project \\ Investigators ${ }^{b}$ \\ bThe University of North Carolina at Chapel Hill, 301 K Peabody Hall \#3500 Chapel Hill, North \\ Carolina, 27599-3500, lynnevf@email.unc.edu
}

\section{Abstract}

Fathers' vocabulary to infants has been linked in the literature to early child language development, however, little is known about the variability in fathers' language behavior. This study considered associations between fathers' work characteristics and fathers' vocabulary among a sample of employed African American fathers of 6-month old infants who were living in low-income rural communities. After controlling for family and individual factors, we found that fathers who worked nonstandard shifts and reported more job flexibility used more diverse vocabulary with their infants.

\section{Keywords}

Parent child communication; Fathers; Infant development; Family work relationship; African American families; Lower income level

\begin{abstract}
Research on early language development has increasingly recognized fathers as key figures in the ecology of children's development (Duursma, Pan, \& Raikes, 2008; Kelley, Smith, Green, Berndt, \& Rogers, 1998; Tamis-LeMonda, Shannon, Cabrera, \& Lamb, 2004). Studies suggest that fathers' language, specifically fathers' vocabulary, is associated with language development for children from low-SES and mid-SES families from diverse ethnic backgrounds (Pancsofar \& Vernon-Feagans, 2006; Pancsofar, Vernon-Feagans, \& The Family Life Project Investigators, 2010). As more mothers have entered the workforce when their children are very young, research has grown on the contributions that fathers make to children's early environments. Studies exploring factors that contribute to variation in fathers' behaviors have reflected a growing awareness of cultural and linguistic diversity in the United States (Cabrera, Tamis-LeMonda, Bradley, Hofferth, \& Lamb, 2000; Gottman, 1998; Parke, 1996; Roopnarine, 2004). The Ecological Systems Theory (Bronfenbrenner, 1979; Bronfenbrenner \& Morris, 1998) suggests that interactions between parents and their children are influenced by external systems including the parents' work environments (Bronfenbrenner, 1986). Parents' work environments impact child development through their influence on family processes including the interactional contexts in which children learn much of their earliest language. Though numerous studies show that characteristics of
\end{abstract}

\footnotetext{
(C) 2012 Elsevier Inc. All rights reserved.

${ }^{\text {a}}$ The College of New Jersey, 2000 Pennington Rd. Ewing, NJ 08618, pancsofa@tcnj.edu, Phone: 609-771-3150. Fax: 609-637-5172, corresponding author.

Publisher's Disclaimer: This is a PDF file of an unedited manuscript that has been accepted for publication. As a service to our customers we are providing this early version of the manuscript. The manuscript will undergo copyediting, typesetting, and review of the resulting proof before it is published in its final citable form. Please note that during the production process errors may be discovered which could affect the content, and all legal disclaimers that apply to the journal pertain.
} 
parents' work impact individual well-being and parenting behaviors (Perry-Jenkins, Goldberg, Pierce, \& Sayer, 2007; Strazdins, Clements, Korda, Broom, \& D’Souza, 2006) we know very little about variability in work characteristics and fathers' language input, particularly among African American fathers with young children. In the current study we examine possible links between work characteristics and the language used by African American fathers in interactions with their young children.

\section{Links Between Fathers' Work Characteristics and Language Input}

\section{Job hours}

Research investigating the work-family interface suggests that work conditions may be particularly important for understanding early interactions between fathers and children (Corwyn \& Bradley, 1999; Crouter, Bumpus, Head, \& McHale, 2001; Doherty, Kouneski, \& Erickson, 1998; Goodman, Crouter, Lanza, Cox, \& The Family Life Project Investigators, 2008; Menaghan, 1991; Perry-Jenkins, Repetti, \& Crouter, 2000; Yeung, Sandberg, DavisKean, \& Hofferth, 2001). It has been hypothesized that among employed fathers, job hours may restrict fathers' time interacting with children; however, studies in this area have yielded mixed results. There is some evidence that fathers' job hours may be negatively associated with the amount of time fathers participate in childcare and reading activities (Aldous, Mulligan, \& Bjarnason, 1998; Marsiglio, 1991; Yeung et al., 2001). For example, Yeung et al. (2001) found that fathers' work hours were negatively associated with the time they spent with their children on weekdays, but not on weekends. However, most studies in this area have been conducted with Caucasian, middle-class families, and Goodman and colleagues (2008) found no effect of work hours on the quality of parent-child interactions in an ethnically diverse, low-income sample (Goodman et al., 2008).

Nonstandard shift work-While it is important to consider the overall amount of time fathers spend working, the time of day the fathers work may also be linked to their parenting behaviors. "Shift work" is used to describe work hours that fall outside of the traditional "9to-5" workday (e.g. working evenings, nights, or rotating shifts) (Beers, 2000). Men are more likely than women to engage in nonstandard shift work, and African Americans are more likely than Whites or Latinos to work alternative shifts (Beers, 2000; Presser, 2003).

Prior research of employed men and women found that nonstandard shift work is associated with a host of negative outcomes, including less time in family roles (Staines \& Pleck, 1984), lower martial quality (White \& Keith, 1990), greater marital instability (Davis, Goodman, Pirretti, \& Almeida, 2008; Presser, 2000), more hostile parenting (Strazdins et al., 2006), and higher levels of parental stress and depressive symptoms (Daniel, Grzywacz, Leerkes, Tucker, \& Han, 2009; Joshi \& Bogen, 2007; Perry-Jenkins et al., 2007). However, some literature suggests that nonstandard shift work may have a differential impact on family relationships for mothers and fathers, and that in some cases, nonstandard shift work may support positive father-child interactions (Mills \& That, 2010; Perry-Jenkins et al., 2007). Mills and Taht (2010) found in a study of Dutch families that fathers with young children who worked nonstandard shifts had less relationship conflict and spent more time with their children. Their quantitative and qualitative analyses suggested that fathers' nonstandard shift work was a strategic choice made by families to build more flexibility into their schedule and for fathers to engage in more childcare and household tasks. Similarly, Wight, Raley, and Bianchi (2008) found that parents who worked nonstandard shifts had more time alone with children than parents who worked standard day shifts. In a sample of two-parent families of 10 to 14 year-old children, Han and Waldfogel (2007) found that mothers' and fathers' nonstandard work schedules were positively associated with some aspects of parenting, such as monitoring, yet negatively associated with other aspects, such as closeness. These results showed that when parents were working nonstandard shifts, it 
was more likely that one of the parents would be present in the home during after school hours. In contrast, it was less likely that children would eat dinner with both parents and parents were more likely to miss important events.

While parents' nonstandard shift work has garnered substantial recent attention in the literature, the mixed findings make it difficult to draw meaningful inferences about the associations between nonstandard shift work and fathering. Nonstandard work schedules may play a more supportive role in fathering at the transition to parenthood as compared to later childhood, but research has yet to illuminate these associations during infancy. For very young children who are not yet in school, nonstandard work schedules may allow fathers to participate more fully in childcare activities and support more optimal father-child interactions. Emerging research on fathers' shift work during early childhood has suggested that nonstandard work schedules may actually support fathers' caregiving and engagement (Brayfield, 1995; Rosenbaum \& Morrett, 2009). In a nationally representative study of dualearner households, Brayfield (1995) found that fathers were more likely to be the primary caregiver for a preschool-aged child when they worked a non-day shift as opposed to a day shift. In a more recent study, Rosenbaum and Morett (2009) found that father-child engagement in cognitively stimulating activities significantly reduced the negative association between parents' work in nonstandard shifts and infant behavior problems. This limited research suggests that fathers' nonstandard work hours may afford fathers of infants greater opportunities to engage in social interactions, and positively influence the way they talk to their young children. However, there have been no studies to consider this association between fathers' nonstandard work hours and fathers' talk to young children.

Job flexibility-Supportive work environments have been linked to more positive fatherchild interactions during infancy for families across SES groups (Goodman et al., 2008; Volling \& Belsky, 1991). One specific aspect of supportive work environments, job flexibility, has been associated with lower levels of work-family conflict and better work and family life balance for mothers and fathers (Allard, Haas, \& Hwang, 2007; Byron, 2005; Hill, Hawkins, Ferris, \& Weitzman, 2001). Job flexibility may grant fathers of young children the ability to manage family and work responsibilities, particularly when challenges related to childcare arise (Hill et al., 2001). However, as a group, African Americans are less likely to have flexible work schedules and family-friendly job benefits than are Caucasians (McLoyd \& Enchautegui-de-Jesus, 2005). Very few, if any, studies have looked at the associations between fathers' job flexibility and the characteristics of father-child interactions during infancy, a developmental period when flexible parental work conditions may be particularly important for supporting optimal language environments for children.

A growing body of research has looked at the links between fathers' work conditions and father-child interactions, however, no study to date has considered how work conditions relate to fathers' talk to their children. Fathers' work conditions may be particularly important in understanding parenting interactions for African-American men (Bowman \& Sanders, 1998). African American men have the lowest labor force participation rates compared to men from other racial groups in the United States (McLoyd \& Enchautegui-deJesus, 2005) and when they are employed, their work conditions tend to be less than ideal. Literature suggests that fathers' employment may be associated with involvement with young children in African American families, with employed fathers demonstrating more involvement with their infants than unemployed fathers (Gavin, Black, Minor, Abel, Papas, $\&$ Bentley, 2002). However, certain work characteristics like shiftwork and job flexibility, that allow African American fathers to be home during the day may be positively associated with high quality verbal interactions with their infant children. 


\section{Demographic Factors and Parent Characteristics Associated with Fathers' Vocabulary}

The association between fathers' work and fathers' vocabulary should be understood while accounting for other meaningful characteristics of fathers and families, including family socio-economic status, the mother-father relationship and individual parent characteristics.

Socio-economic status-The literature consistently links parental language to family socio-economic status and parental education. Research suggests that mothers from higherSES families talk and interact more with their children in ways that are related to more advanced child language development as compared to mothers from lower-SES families (Hammer \& Weiss, 1999; Hart \& Risley, 1995; Hoff, 2006; Hoff, Laursen, \& Tardif, 2002; Hoff-Ginsberg, 1998). Research on fathers within low-SES and middle-SES communities suggests that higher paternal education is associated with more involved caregiving, more frequent engagement in socialization practices, and more harmonious parenting interactions with young children than less paternal education (Ahmeduzzaman \& Roopnarine, 1992; Coley \& Chase-Lansdale, 1999; Duursma et al., 2008; Gavin et al., 2002; Woodworth, Belsky, \& Crnic, 1996; Yogman, Kindlon, \& Earls, 1995). Using nationally representative data on fathers, Cabrera, Hofferth, and Chae (2011) found that fathers' education was related to verbal stimulation and negatively related to physical play with their infants among African American fathers. Among the very few studies to look at the associations between income and verbal behavior of African American fathers, a recent study examined talk about emotions among fathers drawn from the same study population used in the current investigation. This study found that fathers' talk about negative emotions was positively associated with income for African American fathers (Garrett-Peters, Miss-Koonce, Zerwas, Cox, \& The Family Life Project Investigators, 2011). This finding was not replicated among non-African American fathers.

Mother-father relationship_Previous research suggests that characteristics of the mother-father relationship are key predictors of the father-child relationship (Cox, Owen, Lewis, \& Henderson, 1989; Grych, 2002; Kitzmann, 2000; Lamb \& Lewis, 2010). More positive romantic relationships between mothers and fathers have been associated with greater father involvement with infants among African American families (Gavin et al., 2002; Smith, Krohn, Chu, \& Best, 2005). While there are very few studies have considered links between the mother-father relationship and fathers' language input, previous work with preschool and school-aged children has found that greater marital satisfaction was associated with longer fathers' utterances to children (Pratt, Kerig, Cowan, \& Cowan, 1992), while greater marital stress was associated with more negative verbal feedback from fathers (Brody, Pellegrini, \& Sigel, 1986). A more recent study by Pancsofar, Vernon-Feagans, Odom, and Roe (2008) found that in a sample of Caucasian middle-class dual-earner couples, higher levels of marital love and lower levels of family conflict when children were 12 months of age, were associated with more diverse mothers' and fathers' vocabulary in parent-child interactions 1 year later.

Parent characterisics-Because mothers often engage in more parenting responsibilities, even within two-parent households, characteristics of mother-child interactions may influence father-child interactions (Doherty et al., 1998; Lamb \& Lewis, 2010). In triadic interactions between mothers, fathers, and young children, research has shown that mothers engage in more overall talk and may be more involved in keeping the interaction going than fathers (Lindsey \& Caldera, 2006; Pancsofar \& Vernon-Feagans, 2006). While few studies, have specifically considered the influence of mothers' child directed speech on fathers' language input to young children, it is important to control for the potentially meaningful associations between mother-child language interactions and father-child language interactions. 
Additionally, literature links individual characteristics of fathers to their interactions with their children. Specifically, higher levels of depression and distress have been associated with less optimal parent-child communication for both mothers and fathers (Fields, Hernandez-Reif, \& Diego, 2006; Jacob \& Johnson, 1997; Kaplan, Sliter, \& Burgess, 2007). Studies of fathers of infants have found that elevated symptoms of depression in fathers were linked to poorer infant learning in response to paternal speech (Kaplan et al., 2007), less fathers' verbal stimulation, and fewer fathers' caregiving activities with their infants (Cabrera et al., 2011). When considering associations between fathers' work characteristics and father-child vocabulary, it may be important to also control for fathers' role overload, or feeling overwhelmed by multiple commitments. Research has also linked high levels of perceived role overload with a host of negative individual and family-level factors for fathers, including depression, relationship conflict, and a negative family emotional climate (Costigan, Cox, \& Cauce, 2003; Lee, Vernon-Feagans, Vazques, \& Kolak, 2003; PerryJenkins et al., 2007; Wiersma \& Van den Berg, 1991), and high levels of work pressure have been associated with feelings of overload for mothers and fathers (Crouter, Bumpus, Maguire, \& McHale, 1999; Ransford, Crouter, \& McHale, 2008).

\section{Summary}

Fathers' vocabulary during parent-child language interactions has been identified as an important contributor to children's language development during early childhood (Pancsofar \& Vernon-Feagans, 2006; Pancsofar, et al., 2010); however, very little previous research has considered predictors of fathers' language input, particularly within African American families. Research suggests that fathers' work conditions may be related to characteristics of father-child interactions (Gavin et al., 2002; Goodman, et al., 2008; Marsiglio, 1991; Mills \& Taht, 2010; Perry-Jenkins et al., 2007; Wight et al., 2008). However, no study to date has considered these associations between characteristics of fathers' work and the language that fathers direct to their young children during these early interactions. This study addresses these gaps in the literature by investigating the following research question: What are the associations between fathers' work conditions and the vocabulary fathers use with their 6 month old infants? We hypothesized that even after controlling for family SES, characteristics of the mother-father relationship, mothers' vocabulary, and fathers' characteristics, fathers' nonstandard shift work and fathers' job flexibility would be positively related to fathers' vocabulary while longer fathers' job hours would be negatively related to fathers' vocabulary.

\section{Method}

Participants and Design-These data come from the Family Life Project, an ongoing longitudinal study of early child development of children living in low-income rural communities. The Family Life Project used complex sampling procedures to recruit a representative sample of 1,292 infants born to mothers who resided in one of six rural lowincome counties in North Carolina and Pennsylvania, oversampling for African American families in NC, and oversampling for poverty in both regions. All counties had poverty rates (below $200 \%$ poverty level) of around $50 \%$ for children less than 5 years of age. Typical jobs in these areas included customer service representatives, laborers and stock personnel, food preparers, store clerks, bus drivers, and cashiers. These types of jobs often include both standard and nonstandard shift work.

Families in this study were recruited either in person in hospitals at the time of their child's birth or by phone. Phone recruitment occurred for families who resided in target counties but delivered in non-target county hospitals. At both sites, recruitment occurred seven days per week over the 12-month recruitment period spanning September 15, 2003 through September 14, 2004 using a standardized script and screening protocol. Families were 
visited in their homes seven times over the child's first three years of life by project staff who lived in the same counties as the families and who were matched on ethnicity with the families. Respondents self-identified their own race, and at 6 months, 395 primary caregivers identified their children as African American. African American biological fathers resided in the homes of 164 of these families when children were 6 months of age.

Analysis Sample-In the Family Life Project, mothers were the first point of contact and families were considered enrolled in the study with maternal consent and participation obtained at the 2-month visit. This study is focused on families with an employed biological father residing in the household. Biological residential fathers of the enrolled families were invited to participate in the study at 6-month home visits, and African American fathers participated in the study in 114 of the two-parent African American families. Fathers were considered residential if they cohabitated in the household at least 3 nights per week. Of the African American fathers who participated in this study, 90 were employed when their infants were 6 months of age. Full language interaction data were available for 77 of these families. Missing fathers' language data were largely due to recording/sound problems and uncooperative children. Because there were so few African American fathers in Pennsylvania and previous research using this dataset has found associations between state of residence and parenting interactions (Vernon-Feagans, et al., 2008), the decision was made to analyze data for only the African American fathers residing in North Carolina $(n=$ 71).

On many family measures, such as number of children, hours per week in child care, and mothers' employment status, families in this analysis sample were quite similar to African American families in the larger study, including single mother families and two-parent African-American families in which fathers chose not to participate in the study. In African American families with unemployed fathers, children were in childcare for fewer hours per week on average than were children in families with employed fathers. Families included in this study were also better off financially than were single parent families. Two-parent African American families in the larger study, including those with participating and nonparticipating fathers, had, on average, income-to needs ratios between 1.0 and 2.0, falling within the range of low-income families or "working poor." However, single mother African American families, on average, had income-to-needs ratios that fell below the poverty line of 1.0 .

\section{Procedure}

Data presented here were collected during $21 / 2$ hour home visits, when children were 6 months of age. Two separate visits were conducted within 2 weeks of each other. Home visits were conducted by 2 home visitors who simultaneously collected a variety of data from the families, including interviews, questionnaires, and secondary caregiver-child interactions. All interviews and questionnaires in this study were computerized. Thus, interviewers and respondents entered all interview and questionnaire responses into laptop computers, thereby expediting the transfer of data from remote data collection sites to a centrally located data processing center. All caregivers completed the KFAST literacy screener (Kaufman \& Kaufman, 1994). Parents reading at an $8^{\text {th }}$ grade reading level (or beyond) were given the opportunity to complete questionnaires on their own, whereas those who read below an $8^{\text {th }}$ grade reading level had questionnaires read to them.

The specific task from which parent vocabulary was obtained was a picture book task in the home during 6-month visits. Book interactions occurred separately for mothers and fathers. Parents were asked to sit in a comfortable chair or couch with the child and were given the book. Home visitors provided the following instructions to parents: "This is a wordless 
picture book activity for you and [infant's name]. Please 'go through' the book with your child as you normally would. So we can hear what you are saying try not to whisper if possible. When you and [infant's name] are through, just let me know." The book Baby Faces (DK Publishing, 1998) was used for this task. The book was modified so that it contained no words. This wordless picture book contained a picture of a baby face on each page, with each baby showing a different emotion. Parents were given time to go through the book and familiarize themselves with the pictures before beginning the activity. The picture book activity commenced when the parent was given the book and the instructions for the task had ended. The activity ended when the parent signaled to the coder that the activity was completed. The home visitors were told to end the session after 10 minutes if the parent had not signaled he had finished before that point. Fathers wore high quality wireless microphones. All sessions were recorded with a DVD camera to be used for transcription.

\section{Measures}

\section{Socio-economic status}

Demographic data on the families were initially collected at the time of the child's birth and updated at each home interview if information had changed. At each home interview, detailed information was gathered on household composition, including all people who presently lived in the home, household income, as well as other information on years of education, jobs, and race/ethnicity of household members. The variables fathers' education and mothers' education in years was derived from these interview data. The Family Life Project adopted the approach taken by Hanson, McLanahan, and Thomson (1997) of basing household income on anyone who resides in the household, not simply those people related by blood, marriage, or adoption. People were considered to be co-residents if they spend three or more nights per week in the child's household. At each visit, the mother completed a household grid that contained information about each person residing in the household. Household annual income was comprised as a sum of the mothers' reported annual income, the fathers' reported annual income, annualized contributions of all of the other people included in the household grid, and all other sources of income, including unemployment insurance, worker's compensation, social security retirement, other pension, cash income from welfare, child support, interest/dividend income, rental income, alimony, regular help from relatives, and regular help from friends. This annual household total income figure was then divided by the federal poverty threshold for a family of that particular size and composition (thresholds vary based on number of adults and children) to create the incometo-needs ratio. For this study, family income-to-needs ratio was calculated using the family income information collected at home visits and the 2004 poverty threshold values.

\section{Mother-father relationship variables}

Measures of the mother-father relationship included marital status and marital instability. Marital status was derived from 6-month interviews $(1=$ married, $0=$ unmarried $)$.

Relationship instability was measured using the Marital Instability Scale, a 5-items subscale taken from the 13-item Dimension of Marital Quality Scale (Johnson, White, Edwards, \& Booth, 1986). The marital instability scale is used to assess perceptions of relationship instability as well as behaviors such as discussing divorce or breakup. Fathers rated the frequency of markers of relationship instability on a 6-point Likert Scale $(1=$ "Never," $6=$ "Yes, within the past 3 months"). A mean score was constructed such that higher scores reflect greater marital instability. The Cronbach's alpha for the marital instability scale in this study was 0.70 . 


\section{Fathers' characteristics}

Fathers' overload was measured at 6-month visits, using the Role Overload Scale, adapted from Reilly (1982). Fathers rated their agreement on a 5-point Likert Scale (1 = "Strongly agree," $5=$ "Strongly disagree") on 6 items. Items measured the respondent's sense that there was too much to do and not enough time to do it in. Items included "Sometimes I feel as if there are not enough hours in the day" and "There are too many demands on my time." Items were reverse scored and a mean score was constructed such that higher scores reflect greater role overload. The Cronbach's alpha for this measure in this study was 0.86 .

Fathers' depression was measured at 6-month visits, using the Brief Symptoms Index 18 (BSI-18: Derogatis, 2000). The BSI-18 contains eighteen items that are divided evenly across three dimensions: somatization, depression, and anxiety. For this study, only the measure of fathers' depression was used. This scale include 7 items for which responded to how much certain problems had distressed or bothered them during them during the past 7 days, rating items along a 5-point Likert scale ( $0=$ "Not at all," $4=$ "Extremely"). Problems included feeling lonely, feeling no interest in things, and feeling hopeless about the future. A total depression score was computed by summing scores for on these items. The Cronbach's alpha for fathers' depression in this study was 0.84 .

\section{Fathers' work characteristics}

At 6-month visits, fathers were asked to complete a jobs grid, in which they provided information about their work hours, environment, and conditions. The variable, total job hours, refers to the total hours the father worked per week. Fathers reported what hours they usually work for their primary job. The variable, nonstandard shift work, was created as a binary variable in which $1=$ nonstandard shift work (including fixed evening shift, fixed night shift, rotating shift, irregular or other) and $0=$ fixed day shift. Fathers were also asked to answer questions regarding their job flexibility. This 4-item measure was constructed from a collection of questions related to job satisfaction and quality administered to individuals in the 1997 National Study of the Changing Workforce (Bond, Galinsky, \& Swanberg, 1998). Fathers rated their job flexibility on a 4-point Likert Scale (1 = "Strongly agree," 4 = "Strongly disagree"). Items included statements, such as "There is an unwritten rule at my place of employment that you can't take care of family needs on company time." Fathers' job flexibility is the mean of all 4 items. Higher scores reflected greater job flexibility. The Cronbach's alpha for job flexibility scale in this study was 0.71 .

\section{Parent vocabulary}

The software, Systematic Analysis of Language Transcripts (SALT: Miller \& Chapman, 1985) was used to transcribe all of the DVDs of the picture book activities. Highly trained research assistants transcribed the language directed to the child during the session. Transcribers underwent an extensive training process conducted by a senior graduate student and staff. SALT conventions and definitions were developed through weekly group meetings that resulted in a detailed training manual. The training process for transcribers included transcribing 20 transcripts that were then reviewed by a senior graduate student, who watched the DVDs while following the transcript to assure accuracy in transcription conventions. As an ongoing check, this review process continued regularly with all transcribers periodically transcribing the same DVDs and discussing them at weekly research group meetings to ensure consistency in transcription.

Measures of fathers' vocabulary and mothers' vocabulary were derived from the transcripts of father-child and mother-child book interactions when children were 6 months old. The variable, fathers' number of different word roots, was calculated using SALT software. This was determined on the basis of unique free morphemes. Omitted and unintelligible words 
were not included. Variations in the words were not counted as separate root words. For instance, talk and talked would be considered the same root word. These variables measured the number of different words used by parents during their interactions with their infants, and indicates the overall lexical diversity during the picture book activity.

\section{Results}

\section{Preliminary Analyses}

Descriptive statistics were run on each variable, and data were analyzed for outliers and influential cases. Zero-order correlations and means for the variables used in these analyses are presented in Tables 1 and 2. A review of these correlations as well as variance inflation factors demonstrated that there were no issues of multicollinearity in the data.

In order to test our hypotheses and gain a better sense of the unique associations between fathers' work characteristics and the vocabulary fathers used with their infants, we conducted a hierarchical linear regression analysis. Family demographic factors, including fathers' education, mothers' education, family income-to-needs ratio, parent marital status and mother-father relationship instability, were entered in the first step of the regression to control for the potential influence of these variables on fathers' language use with their children. The second step consisted of mothers' vocabulary. The third step consisted of fathers' characteristics of depression and overload. A final step entered paternal work variables, including job hours, job shift, and job flexibility, to the model.

\section{Hierarchical Regression Analysis Predicting Fathers' Vocabulary}

Table 3 presents the results of the hierarchical regression analysis predicting fathers' vocabulary to their 6-month old infants. Demographic factors were entered in Step 1. Only fathers' education was significantly associated with fathers' vocabulary, with more highly educated fathers using a more diverse vocabulary in interactions with their infants $(\beta=.35$, $p=.02$ ). Mothers' vocabulary was entered in Step 2 and fathers' characteristics were entered in Step 3. These variables did not significantly contribute to the model. The addition of fathers' work variables in Step 4 significantly contributed to the model, accounting for an additional $11 \%$ of the variance in fathers' vocabulary $\left(\Delta \mathrm{R}^{2} F=3.89, p=0.01\right)$. Fathers' nonstandard shift work and job flexibility were significantly associated with fathers' vocabulary. Fathers who worked nonstandard shifts used a more diverse vocabulary in interactions with their infants $(\beta=.27, p=.02)$. Further, fathers who reported higher levels of job flexibility used a more diverse vocabulary $(\beta=.27, p=.03)$. The model including all variables, accounted for $25 \%$ of the variance in father vocabulary $(F=3.10, p=0.002)$.

\section{Discussion}

This study suggests that within African American families in low-income rural communities, work characteristics may be meaningful in understanding certain aspects of fathers' language input, such as vocabulary. This study found that African American fathers who worked nonstandard shifts during their child's infancy used a more diverse vocabulary in interactions with their child. In addition, fathers who reported higher job flexibility also used a more diverse vocabulary with their infants. These significant associations were found even after controlling for measures of family socioeconomic status, the mother-father relationship, maternal vocabulary and individual fathers' characteristics.

For African American fathers in this study, working nonstandard shifts during a child's infancy appears to have been supportive of high-quality father-child language interactions. Much of the previous research on nonstandard shift work and parenting has been done with mothers, and these findings have often suggested that maternal nonstandard shift work was 
associated with strained family relationships and less optimal parenting interactions and child developmental outcomes (Daniel et al., 2009; Han, 2005; Joshi \& Bogen, 2007). However, like previous work on fathers, the findings of this study suggest that nonstandard shift work may be associated with more positive father-child interactions (Mills \& Taht, 2010; Perry-Jenkins et al., 2007; Wight et al., 2008). It is possible that mothers and fathers experience parenting demands during infancy differently and that for fathers, nonstandard shift work may actually be associated with greater caregiving responsibility and greater paternal engagement, at least during the early childhood years (Brayfield, 1995).

Nonstandard shift work may support high-quality father-child language interactions early in the parenthood experience.

It was also found that greater job flexibility was also associated with more diverse fathers' vocabulary. While there has been little previous research on the association between job flexibility and fathering, job flexibility may allow fathers a greater measure of control in response to the unpredictable demands of infant care (Barnett, 1994; Hill et al., 2001). For example, job flexibility may allow parents to attend to their children's development needs while maintaining employment (McLoyd \& Enchautegui-de-Jesus, 2005). However, as McLoyd and Enchautegui-de-Jesus note, African American parents are less likely than Caucasian parents to have flexible work conditions and other family-friendly benefits. Job flexibility may be particularly meaningful in supporting high-quality parenting interactions for African American fathers experiencing more dire financial constraints, as research indicates that low-income families often experience a greater frequency and intensity of stressful life events and parenting hassles (Evans, 2004).

In this study, fathers' job hours were not uniquely associated with their language in interactions with their infants at 6 months. While it has been hypothesized in previous research that job hours may restrict fathers' time with their children and negatively impact the quality of parenting interactions, other studies of low-income and ethnically diverse samples of fathers have also found no effects of work hours on the quality of parent-child interactions (Goodman, et al., 2008). These findings suggest that the associations between fathers' employment and job hours may be complex in low-income communities where employment can be scarce and unstable. In these communities, it may be the conditions associated with employment, rather than the overall hours, that are meaningful for understanding fathering interactions with young children.

This study controlled for a host of family factors and individual fathers' characteristics. While associations between control variables and fathers' vocabulary were largely nonsignificant, there was a significant positive association between fathers' education and fathers' vocabulary. In this study, fathers with more education used a more diverse vocabulary with their children. This finding is consistent with research on maternal education and maternal language input (Hammer \& Weiss, 1999; Hart \& Risley, 1995; Hoff, 2006; Hoff et al., 2002; Hoff-Ginsberg, 1998) as well as an expanding area of research that has focused on fathers' education and father-child interactions/stimulation (Ahmeduzzaman \& Roopnarine, 1992; Cabrera et al., 2011; Coley \& Chase-Lansdale, 1999; Duursma et al., 2008; Gavin et al., 2002). Moreover, our finding on the positive association between fathers' education and vocabulary lends empirical support to the argument that the amount and quality of education may be particularly salient in the lives of African American fathers and their children (Ahmeduzzaman \& Roopnarine, 1992; Coley \& Chase-Lansdale, 1999). High school drop-out rates remain higher among African American youth than Caucasian youth (Kaufman, Alt, \& Chapman, 2001), and African American men have lower rates of participation in postsecondary education than do Caucasian men, Caucasian women and African American women (Hudson, Aquilino, \& Kienzi, 2005). Programmatic efforts and policies that facilitate African American men and fathers obtaining higher levels of 
education or job skills training may positively impact the quality of father-child language interactions.

The results of this study should be interpreted with an awareness of the limitations of this sample. This study was concerned with the language input of biological resident fathers who were likely to be regularly interacting with their young infants. Previous research has identified the language use of biological resident fathers during early childhood to be significantly associated with children's subsequent language development, across fathers' ethnicity and family SES (Pancsofar \& Vernon-Feagans, 2006; Pancsofar, et al., 2010). However, a focus on biological resident fathers narrowed the scope of this study and has perhaps limited the generalizability of these findings. Future studies should consider the role of fathers' work in fathers' language use among nonresident fathers, as well as father figures and social fathers, who may also play an important role in the development of young African American children (Coley, 2001). This study considered associations between fathers' work variables and language use at a single time point during infancy. Future work is needed to better understand the trajectories of these associations over time, and to consider other factors such as stability and change in fathers' work as they relate to fatherchild language interactions. Further, future research should also look at possible interdependencies in the work situations of mothers and fathers as they relate to characteristics of parent language input.

Lastly, in interpreting these findings on fathers' language input, it is important to note the context in which fathers' vocabulary was measured in this study. Because the young children in this study were nonverbal, measures of fathers' vocabulary were largely free from the confounding role of child language. However, it is unclear how fathers' talk to their children might change as their children age. Associations between characteristics of fathers' work and fathers' vocabulary need to be explored more closely across children's early childhood years. Further, fathers' language in this study was measured in the context of a picture book activity. While joint picture book activities are an important context for the study of parent language, this context may differ from other important contexts of fatherchild daily interaction, such as during play activities. Future work in this area is needed to better understand the linguistic characteristics of father-child interactions across multiple parenting contexts.

This study has implications for professional practice and future research by highlighting important links between fathers' language input and broader nonfamilial contexts. Perhaps because so much is known about mother-child interactions, family support programs and interventions have historically focused their efforts on mothers (Brooks-Gunn, Berlin, \& Fuligni, 2000; Turbiville \& Marquis, 2001), however, in recent years, there have been increased efforts to understand fathers' participation in such programs (Elder, Valcante, Yarandi, White, \& Elder, 2005; Roggman, Boyce, Cookie, \& Cook, 2002). Fathers are key figures in the ecology of children and practitioners need to give specific attention to supporting high quality father-child language interactions. Practitioners should be aware of the ways that father-child interactions may be influenced by broader contexts, such as fathers' education and work. For example, professionals working with fathers of young children should be aware of father job characteristics, including job shift and flexibility. Early intervention efforts aimed at supporting children's early language development may benefit from including educational support and employment counseling for fathers. Future research is needed in this area to more fully address the utility of addressing fathers' education and work within the scope of family support programs and therapies, as well as early intervention services. 
The results of this study may also provide guidance for policy initiatives aimed at supporting fathering in low-income rural communities. African American men have the lowest labor force participation rates compared to men from other racial groups in the United States (McLoyd \& Enchautegui-de-Jesus, 2005), and when they are employed, their work conditions tend to be less than optimal, with African Americans less likely to have flexible work schedules and family-friendly job benefits than Caucasians (McLoyd \& Enchauteguide-Jesus, 2005). Policy efforts should focus not on only increasing employment opportunities for African American men in low-income rural communities, but also on supporting opportunities for jobs that are flexible and family-friendly. Optimizing these key work characteristics for African American fathers, particularly during the early childhood period, may be important in supporting rich language learning contexts for their young children through high quality father-child language interactions.

\section{Acknowledgments}

Support for this research was provided by the National Institute of Child Health and Human Development (PO1HD-39667), with co-funding from the National Institute on Drug Abuse. The Family Life Project (FLP) Key Investigators include Lynne Vernon Feagans, Martha Cox, Clancy Blair, Peg Burchinal, Linda Burton, Keith Crnic, Ann Crouter, Patricia Garrett-Peters, Mark Greenberg, Stephanie Lanza, Roger Mills-Koonce, Debra Skinner, Emily Werner, and Michael Willoughby. Erika Odom also received funding from the Institute for Education Sciences Post-Doctoral Research Fellowship.

\section{References}

Ahmeduzzaman M, Roopnarine JL. Sociodemographic factors, functioning style, social support, and fathers' involvement with preschoolers in African-American families. Journal of Marriage and the Family. 1992; 54:699-707. doi:10.2307/353255.

Aldous J, Mulligan GM, Bjarnason T. Fathering over time: What makes the difference? Journal of Marriage and the Family. 1998; 60:809-820. doi:10.2307/353626.

Allard K, Haas L, Hwang P. Exploring the paradox: Experiences of flexible working arrangements and work-family conflict among managerial fathers in Sweden. Community, Work, and Family. 2007; 10:475-493. doi:10.1080/13668800701575135.

Barnett RC. Home-to-work spillover revisited: A study of full-time employed women in dual-earner couples. Journal of Marriage and the Family. 1994; 56:647-656. doi:10.2307/352875.

Beers TM. Flexible schedules and shift work: Replacing the '9-to-5' workday. Monthly Labor Review. 2000; 123:33-40. Retrieved from http://www.bls.gov/opub/mlr/welcome.htm.

Bond, JT.; Galinsky, E.; Swanberg, JE. The 1997 National study of the changing workforce. Families and Work Institute; New York, NY: 1998.

Bowman PJ, Sanders R. Unmarried African American fathers: A comparative life span analysis. Journal of Comparative Family Studies. 1998; 29:35-56. Retrieved from soci.ucalgary.ca/jcfs.

Brayfield A. Juggling job and kids: The impact of employment schedules on fathers' caring for children. Journal of Marriage and Family. 1995; 57:321-332. doi:10.2307/353686.

Brody GH, Pellegrini AD, Sigel IE. Marital quality and mother-child and father-child interactions with school-aged children. Developmental Psychology. 1986; 22:291-296. doi: 10.1037//0012-1649.22.3.291.

Bronfenbrenner U. Contexts of child rearing. American Psychologist. 1979; 34:844-858. doi: 10.1037//0003-066X.34.10.844.

Bronfenbrenner $\mathrm{U}$. The ecology of the family as a context for human development: Research perspectives. Developmental Psychology. 1986; 22:723-742. doi:10.1037//0012-1649.22.6.723.

Bronfenbrenner, U.; Morris, PA. The ecology of developmental processes. In: Damon, W.; Lerner, RM., editors. Handbook of child psychology. Wiley; New York, NY: 1998. p. 993-1028.

Brooks-Gunn, J.; Berlin, L.; Fuligni, A. Early childhood intervention programs: What about the family?. In: Shonkoff, JP.; Meisels, SJ., editors. Handbook of early childhood intervention. 2nd ed.. Cambridge University Press; Cambridge, MA: 2000. p. 549-588. 
Byron K. A meta-analytic review of work-family conflict and its antecedents. Journal of Vocational Behavior. 2005; 67:169-198. doi:10.1016/j.jvb.2004.08.009.

Cabrera NJ, Hofferth SL, Chae S. Patterns and predictors of father-infant engagement across race/ethic groups. Early Childhood Research Quarterly. 2011; 26:365-375. doi:10.1016/j.ecresq. 2011.01.001. [PubMed: 22110258]

Cabrera NJ, Tamis-LeMonda CS, Bradley RH, Hofferth S, Lamb ME. Fatherhood in the Twenty-first Century. Child Development. 2000; 71:127-136. doi:10.1111/1467-8624.00126. [PubMed: 10836566]

Coley RL. (In)visible men: Emerging research on low-income, unmarried, and minority fathers. American Psychologist. 2001; 56:743-753. doi:10.1037//0003-066X.56.9.743. [PubMed: 11558359]

Coley RL, Chase-Lansdale PL. Stability and change in paternal involvement among urban African American fathers. Journal of Family Psychology. 1999; 13:416-435. doi: 10.1037//0893-3200.13.3.416.

Corwyn RF, Bradley RH. Determinants of paternal and maternal investment in children. Infant Mental Health Journal. 1999; 20:238-256. doi:10.1002/(SICI)1097-0355(199923)20:3<238::AIDIMHJ3>3.0.CO;2-\#.

Costigan CL, Cox MJ, Cauce AM. Work-parenting linkages among dual-earner couples at the transition to parenthood. Journal of Family Psychology. 2003; 17:397-408. doi: 10.1037/0893-3200.17.3.397. [PubMed: 14562463]

Cox MJ, Owen MT, Lewis JM, Henderson VK. Marriage, adult adjustment, and early parenting. Child Development. 1989; 60:1015-1024. doi:10.2307/1130775. [PubMed: 2805879]

Crouter AC, Bumpus MF, Head MR, McHale SM. Implications of overwork and overload for quality of men's family relationships. Journal of Marriage and Family. 2001; 63:404-416. doi:10.1111/j. 1741-3737.2001.00404.x.

Crouter AC, Bumpus MF, Maguire MC, McHale SM. Linking parents' work pressure and adolescents' well-being: Insights into dynamics in dual-earner families. Developmental Psychology. 1999; 35:1453-1461. doi:10.1037//0012-1649.35.6.1453. [PubMed: 10563734]

Baby Faces. D K Publishing; 1998.

Daniel SS, Grzywacz JG, Leerkes E, Tucker J, Han W. Nonstandard maternal work schedules during infancy: Implications for children's early behavior problems. Infant Behavior and Development. 2009; 32:195-207. doi:10.1016/j.infbeh.2008.12.008. [PubMed: 19233479]

Davis KD, Goodman WB, Pirretti AE, Almeida DM. Nonstandard work schedules, perceived family well-being, and daily stressors. Journal of Marriage and Family. 2008; 70:991-1003. doi:10.1111/ j.1741-3737.2008.00541.x. [PubMed: 19194531]

Derogatis, L. Brief Symptom Inventory. Vol. 18. NCS Pearson, Inc.; Minneapolis, MN: 2000.

Doherty WJ, Kouneski EF, Erickson MF. Responsible fathering: An overview and conceptual framework. Journal of Marriage and the Family. 1998; 60:277-292. doi:10.2307/353848.

Dunst CJ, Leet HE. Measuring the adequacy of resources in households with young children. Child: Care, Health, and Development. 1987; 13:111-125. doi:10.1111/j.1365-2214.1987.tb00528.x.

Duursma E, Pan BA, Raikes H. Predictors and outcomes of low-income fathers' reading with their toddlers. Early Childhood Research Quarterly. 2008; 23:351-365. doi:10.1016/j.ecresq. 2008.06.001.

Elder JH, Valcante G, Yarandi H, White D, Elder TH. Evaluating in-home training for fathers of children with autism using single-subject experimentation and group analysis methods. Nursing Research. 2005; 54:22-32. doi:10.1097/00006199-200501000-00004. [PubMed: 15695936]

Evans GW. The environment of childhood poverty. American Psychologist. 2004; 59:77-92. doi: 10.1037/0003-066X.59.2.77. [PubMed: 14992634]

Fields T, Hernandez-Reif M, Diego M. Intrusive and withdrawn depressed mothers and their infants. Developmental Review. 2006; 26:15-30. doi:10.1016/j.dr.2005.04.001.

Garrett-Peters P, Mills-Koonce R, Zerwas S, Cox M, The Family Life Project Investigators. Fathers' early emotion talk: Associations with income, ethnicity, and family factors. Journal of Marriage and Family. 2011; 73:335-353. doi: 10.1111/j.1741-3737.2010.00810.x. 
Gavin LE, Black MM, Minor S, Abel Y, Papas MA, Bentley ME. Young, disadvantaged fathers' involvement with their infants: An ecological perspective. Journal of Adolescent Health. 2002; 31:266-276. doi:10.1016/S1054-139X(02)00366-X. [PubMed: 12225739]

Goodman WB, Crouter AC, Lanza ST, Cox MJ, The Family Life Project Investigators. Paternal work characteristics and father-infant interactions in low-income, rural families. Journal of Marriage and Family. 2008; 70:640-653. doi:10.1111/j.1741-3737.2008.00511. [PubMed: 20011453]

Gottman, JM. Toward a process model of men in marriages and families. In: Booth, A.; Crouter, AC., editors. Men in families: When do they get involved? What difference does it make? Lawrence Erlbaum Associates; Mahwah, NJ: 1998. p. 149-193.

Grych, JH. Marital relationships and parenting. In: Bornstein, M., editor. Handbook of parenting. Vol. 4: Social conditions and applied parenting. Erlbaum; Mahwah, N.J.: 2002. p. 203-225.

Hammer CS, Weiss AL. Guiding language development: How African American mothers and their infants structure play interactions. Journal of Speech, Language, and Hearing Research. 1999; 42:1219-1233. Retrieved from jslhr.asha.org.

Han W. Maternal nonstandard work schedules and child cognitive outcomes. Child Development. 2005; 76:137-154. doi:10.1111/j.1467-8624.2005.00835.x. [PubMed: 15693763]

Han W, Waldfogel J. Parental work schedules, family process, and early adolescents' risky behavior. Children and Youth Services Review. 2007; 29:1249-1266. doi:10.1016/j.childyouth.2007.05.011.

Hanson, TL.; McLanahan, S.; Thomson, E. Economic resources, parental practices, and children's well-being. In: Duncan, G.; Brooks-Gunn, J., editors. Consequences of growing up poor. Russell Sage Foundation; New York, NY: 1997. p. 190-221.

Hart, B.; Risley, T. Meaningful differences in the everyday experience of young American children. Brookes; Baltimore, MD: 1995.

Hill EJ, Hawkins AJ, Ferris M, Weitzman M. Finding an extra day a week: The positive influence of perceived job flexibility on work and family life balance. Family Relations. 2001; 50:49-58. doi: 10.1111/j.1741-3729.2001.00049.x.

Hoff E. How social contexts support and shape language development. Developmental Review. 2006; 26:55-88. doi:10.1016/j.dr.2005.11.002.

Hoff, E.; Laursen, B.; Tardif, T. Socioeconomic status and parenting. In: Bornstein, MH., editor. Handbook of parenting: Vol.2: Biology and ecology of parenting. Erlbaum; Mahwah, NJ: 2002. p. 231-252.

Hoff-Ginsberg E. The relation of birth order and socioeconomic status to children's language experience and language development. Applied Psycholinguistics. 1998; 19:603-629. doi:10.1017/ S0142716400010389.

Hudson, L.; Aquilino, S.; Kienzi, G. Postsecondary participation rates by sex and race/ethnicity: 1974-2003. U.S. Department of Education; National Center for Education Statistics; Washington DC: 2005. NCES 2005-028Retrieved January 17, 2010 from http://nces.ed.gov/pubsearch/ pubsinfo.asp?pubid=2005028

Jacob T, Johnson SL. Parent-child interaction among depressed fathers and mothers: Impact on child functioning. Journal of Family Psychology. 1997; 11:391-409. doi:10.1037//0893-3200.11.4.391.

Johnson DR, White LK, Edwards JN, Booth A. Dimensions of marital quality: Toward methodological and conceptual refinement. Journal of Family Issues. 1986; 7:31-49. doi: $10.1177 / 019251386007001003$.

Joshi P, Bogen K. Nonstandard schedules and young children's behavioral outcomes among working low-income families. Journal of Marriage and the Family. 2007; 69:139-156. doi: 10.1111/j. 1741-3737.2006.00350.x.

Kaplan PS, Sliter JK, Burgess AP. Infant-directed speech produced by fathers with symptoms of depression: Effects on infant associative learning in a conditioned-attention paradigm. Infant Behavior and Development. 2007; 30:535-545. doi:10.1016/j.infbeh.2007.05.003. [PubMed: 17604106]

Kaufman, P.; Alt, MN.; Chapman, C. Dropout rates in the United States: 2000. U.S. Department of Education; National Center for Education Statistics; Washington DC: 2001. NCES 2002-114Retrieved January 17, 2010 from http://nces.ed.gov/pubsearch/pubsinfo.asp? pubid $=2002114$ 
Kaufman, AS.; Kaufman, NL. Kaufman Functional Academic Skills Test (K-FAST). American Guidance Service; Circle Pines, MN: 1994.

Kelley ML, Smith TS, Green AP, Berndt AE, Rogers MC. Importance of fathers' parenting to African American toddler's social and cognitive development. Infant Behavior and Development. 1998; 21:733-744. doi:10.1016/S0163-6383(98)90041-8.

Kitzmann KM. Effects of marital conflict on subsequent triadic family interactions and parenting. Developmental Psychology. 2000; 36:3-13. doi:10.1037//0012-1649.36.1.3. [PubMed: 10645740]

Lamb, ME.; Lewis, C. The role of the father in child development. 5th ed.. John Wiley \& Sons, Inc.; Hoboken, NJ: 2010. The development and significance of father-child relationships in two-parent families; p. 94-153.

Lee M, Vernon-Feagans L, Vazquez A, Kolak A. The influence of family environment and child temperament on work/family role strain for mothers and fathers. Infant and Child Development. 2003; 12:421-439. doi:10.1002/icd.323.

Lindsey EW, Caldera YM. Mother-father-child triadic interaction and mother-child dyadic interaction: Gender differences within and between contexts. Sex Roles. 2006; 55:511-521. doi:10.1007/ s11199-006-9106-z.

Marsiglio W. Paternal engagement activities with minor children. Journal of Marriage and the Family. 1991; 53:973-986. doi:10.2307/353001.

McLoyd, VC.; Enchautegui-de-Jesus, N. Work and African American family life. In: McLoyd, VC.; Hill, NE.; Dodge, KA., editors. African American family life: Ecological and cultural diversity. The Guilford Press; New York, NY: 2005. p. 135-165.

Menaghan EG. Work experiences and family interaction processes: The long reach of the job? Annual Review of Sociology. 1991; 17:419-444. doi:10.1146/annurev.soc.17.1.419.

Miller, JF.; Chapman, RS. Systematic Analysis of Language Transcripts. Language Analysis Laboratory; Waisman Center on Mental Retardation and Human Development; University of Wisconsin-Madison; Madison, WI: 1985.

Mills M, Taht K. Nonstandard work schedules and partnership quality: Quantitative and qualitative findings. Journal of Marriage and the Family. 2010; 72:860-875. doi:10.1111/j. 1741-3737.2010.00735.x.

Pancsofar N, Vernon-Feagans L. Mother and father language input to young children: Contributions to later language development. Journal of Applied Developmental Psychology. 2006; 27:571-587. doi:10.1016/j.appdev.2006.08.003.

Pancsofar N, Vernon-Feagans L, Odom E, Roe J. Family relationships during infancy and later mother and father vocabulary use with young children. Early Childhood Research Quarterly. 2008; 23:493-503. doi:10.1016/j.ecresq.2008.07.001. [PubMed: 19169439]

Pancsofar N, Vernon-Feagans L, The Family Life Project Investigators. Fathers' early contributions to children's language development in families from low-income rural communities. Early Childhood Research Quarterly. 2010; 25:450-463. doi:10.1016/j.ecresq.2010.02.001. [PubMed: 21057648]

Parke, R. Fatherhood. Harvard University Press; Cambridge MA: 1996.

Perry-Jenkins M, Goldberg AE, Pierce CP, Sayer AG. Shift work, role overload, and the transition to parenthood. Journal of Marriage and the Family. 2007; 69:123-138. doi:10.1111/j. 1741-3737.2006.00349.x. [PubMed: 20216932]

Perry-Jenkins M, Repetti RL, Crouter AC. Work and family in the 1990's. Journal of Marriage and the Family. 2000; 62:981-998. doi: 10.1111/j.1741-3737.2000.00981.x.

Pratt MW, Kerig PK, Cowan PA, Cowan CP. Family worlds: Couple satisfaction, parenting style, and mothers' and fathers' speech to young children. Merrill-Palmer Quarterly. 1992; 38:245-262. doi: 1992-27076-001.

Presser HB. Nonstandard work schedules and marital instability. Journal of Marriage and the Family. 2000; 62:93-110. doi:10.1111/j.1741-3737.2000.00093.x.

Presser HB. Race-ethnic and gender differences in nonstandard work shifts. Work and Occupations. 2003; 30:412-439. doi:10.1177/0730888403256055. 
Ransford CR, Crouter AC, McHale SM. Implications of work pressure and supervisor support for fathers' and mothers' and adolescents' relationships and well-being in dual-earner families. Community, Work, and Family. 2008; 11:37-60. doi:10.1080/13668800701785312.

Reilly MD. Working wives and convenience consumption. Journal of Consumer Research. 1982; 8:407-418. doi:10.1086/208881.

Roggman LA, Boyce LK, Cookie GA, Cook J. Getting dads involved: Predictors of father involvement in Early Head Start and with their children. Infant Mental Health Journal. 2002; 23:62-78. doi: 10.1002/imhj.10004.

Roopnarine, JL. African American and African Caribbean fathers: Level, quality and meaning of involvement. In: Lamb, ME., editor. The role of the father in child development. 4th ed.. John Wiley \& Sons, Inc.; Hoboken, NJ: 2004. p. 58-97.

Rosenbaum E, Morett CR. The effect of parents' joint work schedules on infants' behavior over the first two years of life: Evidence from the ECLSB. Maternal and Child Health Journal. 2009; 13:732-744. doi:10.1007/s10995-009-0488-8. [PubMed: 19543818]

Smith CA, Krohn MD, Chu R, Best O. African American fathers: Myths and realities about their involvement with their firstborn children. Journal of Family Issues. 2005; 26(7):975-1001. doi: 10.1177/0192513X05275421.

Staines GL, Pleck JH. Nonstandard work schedules and family life. Journal of Applied Psychology. 1984; 69:515-523. doi:10.1037//0021-9010.69.3.515.

Strazdins L, Clements MS, Korda RJ, Broom DH, D’Souza RM. Unsociable work? Nonstandard work schedules, family relationships, and children's well-being. Journal of Marriage and the Family. 2006; 68:394-410. doi:10.1111/j.1741-3737.2006.00260.x.

Tamis-LeMonda CS, Shannon JD, Cabrera NJ, Lamb ME. Fathers and mothers at play with their 2and 3-year-olds: Contributions to language and cognitive development. Child Development. 2004; 75:1806-1820. doi:10.1111/j.1467-8624.2004.00818.x. [PubMed: 15566381]

Turbiville VP, Marquis JG. Father participation in early education programs. Topics in Early Childhood Special Education. 2001; 21:223-231. doi:10.1177/027112140102100403.

Vernon-Feagans L, Pancsofar N, Willoughby M, Odom E, Quade A, Cox M, et al. Predictors of maternal language to infants during a picture book task in the home: Family SES, child characteristics and the parenting environment. Journal of Applied Developmental Psychology. 2008; 29:213-226. doi:10.1016/j.appdev.2008.02.007. [PubMed: 18618023]

Volling BL, Belsky J. Multiple determinants of father involvement during infancy in dual-earner and single-earner families. Journal of Marriage and the Family. 1991; 53:461-474. doi: $10.2307 / 352912$.

White L, Keith B. The effect of shift work on the quality and stability of marital relations. Journal of Marriage and the Family. 1990; 52:453-462. doi:10.2307/353039.

Wiersma UJ, Van den Berg P. Work-home role conflict, family climate, and domestic responsibilities among men and women in dual-earner families. Journal of Applied Social Psychology. 1991; 21:1207-1217. doi:10.1111/j.1559-1816.1991.tb00466.x.

Wight VR, Raley SB, Bianchi SM. Time for children, one's spouse, and oneself among parents who work nonstandard hours. Social Forces. 2008; 87:243-274. doi: 10.1353/sof.0.0092.

Woodworth S, Belsky J, Crnic K. The determinants of fathering during the child's second and third years of life: A developmental analysis. Journal of Marriage and the Family. 1996; 58:679-692. doi:10.2307/353728.

Yeung WJ, Sandberg JF, Davis-Kean PE, Hofferth SL. Children's time with fathers in intact families. Journal of Marriage and the Family. 2001; 63:136-154. doi:10.1111/j.1741-3737.2001.00136.x.

Yogman MW, Kindlon D, Earls F. Father involvement and cognitive/behavioral outcomes of preterm infants. Journal of American Academy of Child and Adolescent Psychiatry. 1995; 34:58-66. doi: 10.1097/00004583-199501000-00015. 


\section{Table 1}

Descriptive statistics: Background characteristics, father characteristics, work experiences and vocabulary at 6 months $(\mathrm{n}=71)$

\begin{tabular}{lrc}
\hline & Mean & \multicolumn{1}{c}{ sd } \\
\hline SES & & \\
Mother education in years & 12.68 & 1.55 \\
Father education in years & 12.15 & 1.43 \\
Family income-to-needs ratio & 1.89 & 0.99 \\
Mother-father relationship & & \\
Marital status (married $=1)$ & 0.70 & 0.46 \\
Relationship instability & 1.89 & 1.01 \\
Mother vocabulary diversity & 66.17 & 29.83 \\
Father characteristics & & \\
Depression & 46.35 & 6.97 \\
Role overload & 2.92 & 1.06 \\
Father work experiences & & \\
Hours & 44.62 & 12.24 \\
Shift ${ }^{a}$ (Nonstandard = 1) & 0.31 & 0.47 \\
Flexibility & 2.69 & 0.74 \\
Father vocabulary diversity & 60.79 & 31.41 \\
\hline
\end{tabular}

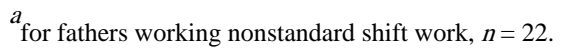




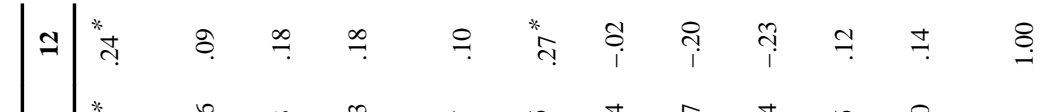

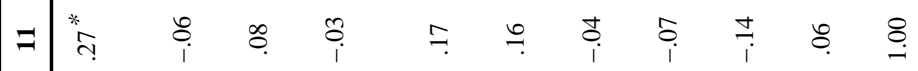

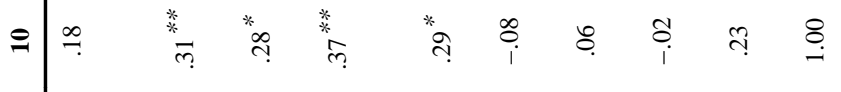

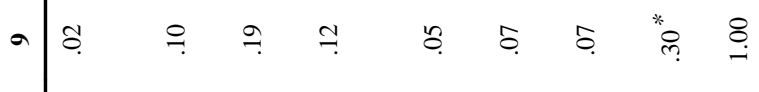

$$
\begin{aligned}
& \infty \quad \& \quad \& \text { \&. }
\end{aligned}
$$

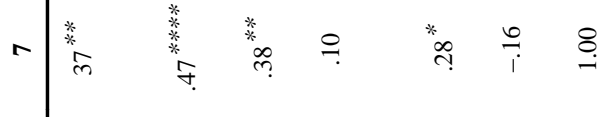

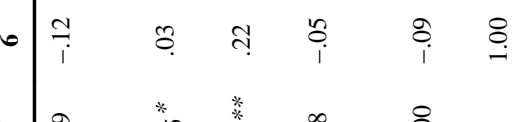

$$
\begin{aligned}
& \text { in }
\end{aligned}
$$

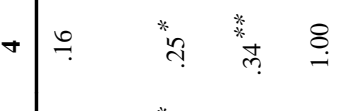

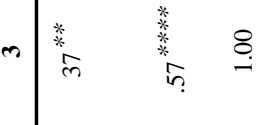

$$
\begin{aligned}
& \text { ก กิ } \\
& -\stackrel{8}{-}
\end{aligned}
$$

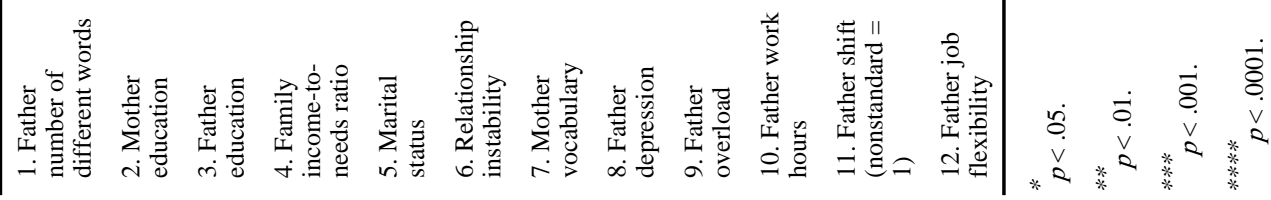




\section{Table 3}

Summary of the hierarchical linear regression analysis predicting father vocabulary $(\mathrm{n}=71)$

\begin{tabular}{|c|c|c|}
\hline Independent variable & $\boldsymbol{B}$ & $S E B$ \\
\hline \multicolumn{3}{|l|}{ Step 1: Demographic controls } \\
\hline Mother education in years & -0.10 & 2.76 \\
\hline Father education in years & $7.79^{*}$ & 3.28 \\
\hline Family income-to-needs ratio & 0.05 & 3.78 \\
\hline Marital status & 11.00 & 8.19 \\
\hline Relationship instability & -5.61 & 3.63 \\
\hline \multicolumn{3}{|l|}{$R^{2}=.14, F(5,65)=3.21^{*}$} \\
\hline \multicolumn{3}{|l|}{ Step 2: Mother language input } \\
\hline Mother vocabulary & 0.24 & 0.14 \\
\hline \multicolumn{3}{|l|}{$\Delta R^{2}=.02, F$ change $(1,64)=3.06$} \\
\hline \multicolumn{3}{|l|}{ Step 3: Father characteristics } \\
\hline Father depression & 0.29 & 0.55 \\
\hline Father overload & -2.19 & 3.54 \\
\hline \multicolumn{3}{|l|}{$\Delta R^{2}=-.02, F$ change $(2,62)=0.26$} \\
\hline \multicolumn{3}{|l|}{ Step 4: Father work conditions } \\
\hline Work hours & 0.08 & 0.32 \\
\hline $\begin{array}{l}\text { Nonstandard shift work } \\
(\text { nonstandard hours }=1)\end{array}$ & $18.39^{*}$ & 7.46 \\
\hline Job flexibility & $11.34^{*}$ & 5.09 \\
\hline \multicolumn{3}{|l|}{$\Delta R^{2}=.11, F$ change $(3,59)=3.89^{*}$} \\
\hline \multicolumn{3}{|l|}{${ }^{*} p<.05$} \\
\hline \multicolumn{3}{|l|}{$p<.01$} \\
\hline \multicolumn{3}{|l|}{ **** } \\
\hline$* * * * * 0.0001$ & & \\
\hline
\end{tabular}

